\title{
The Sputnik fable
}

\section{Oversimplifying the effect of the space race on US science funding could lead scientists down the wrong path, says David Goldston.}

$\mathrm{n}$ these days of economic uncertainty and
political transition, science advocates under-
standably seek guidance (and solace) from an earlier age when, supposedly, the issues were clearer and success was assured. As a result, a common refrain in speeches and articles is that what's needed to jump-start US research spending now is a 'Sputnik moment'. But this longing for the hysteria that attended the 1957 launch of the Soviet satellite fosters undue pessimism about today - and is as likely to hamper advocates' goals as to spur them.

The problem with the Sputnik trope is that it makes the 1950s look too simple and later periods look too bleak. The false simplicity leads scientists to believe that it was once possible to push for funding without getting tangled in politics, and the false bleakness leads them to conclude that the only way to win public support for science is to posit a crisis and claim to be able to resolve it.

The standard version of the Sputnik fable is a kind of morality tale that goes more or less like this: in the 1950s, the United States was a laggard in science and technology, which was demonstrated starkly when the Soviet Union launched the world's first satellite. In response, the American public and politicians saw the error of their ways and reacted forcefully, increasing investments in research and education across the board. That put the United States in the scientific vanguard for at least a decade until the nation began to forget the lessons of Sputnik, allowing new rivals such as Japan to begin to eat away at its lead.

There is some truth to this narrative; science spending did increase in response to Sputnik, and new agencies such as NASA were created. But all the particulars are wrong, and the story obscures as much as it illuminates. The whole debate around responding to Sputnik was highly politicized, with Congress trying to showcase concrete actions and President Dwight Eisenhower trying to resist what he saw as an excessive response given that US satellite programmes were not actually behind those of the Soviets. Research spending was already increasing before the Sputnik launch, and the increases that followed it were highly concentrated in the areas of defence and space, and allocated more to development than to research. around the 2005 National Academy of Sciences report Rising Above the Gathering Storm, for example, ought to be careful not to oversell their wares.

It's interesting in that regard that the Sputnik myth tends to ignore the later history of NASA, the satellite's offspring. The space race was the only widely accepted rationale for the agency, and its human spaceflight programmes have been fumbling around for purpose, money and support ever since the cold war crisis began to wane. NASA proponents now wonder why the agency isn't included in plans to increase research spending to improve economic competitiveness, forgetting that the Sputnik moment was tied specifically to the Soviet threat and did not benefit all agencies equally.

The reaction to the Arab oil embargoes of the 1970s - an acute threat that could be addressed in part with technology, arguably the closest thing to a Sputnik moment since the 1950s - offers a similar cautionary tale. Spending on energy research climbed in the immediate aftermath of the crisis, but then plummeted along with oil prices and the belief in government programmes that came under attack from President Ronald Reagan.

Happily, scientists seem to be drawing the right lessons from the 1970s, at least in the energy realm: don't focus excessively on the immediate crisis, don't promise too many benefits too quickly, and don't assume spending on your pet projects can thrive in a political atmosphere that is hostile to government programmes in general. As President-elect Barack Obama is putting together his energy plan, groups such as the American Physical Society (APS) are rightly calling for a mixture of shorter- and longer-term research while acknowledging that the research needs to be coupled with new energy policies if it is to make a difference. (I served as a co-chair for the recent APS study.)

As George Orwell put it, whoever controls the past controls the future. The stories we tell about the past influence how we go about building the future and how we respond to political obstacles today. The Sputnik itself was benign, but the heroic tale that it spawned can cause real damage. Scientists present the story as a heartening and apolitical Aesopian fable: science is first ignored, then the need for it is recognized by all, and then it rides singlehandedly to the rescue of the nation. That has left the scientific community far too easily discouraged when it confronts the real political world and needlessly short of stories to deploy on its own behalf.

David Goldston is a project director at the Bipartisan Policy Center in Washington DC. Reach him at partyofonecolumn@gmail.com. materialize or the crisis passes. Those waving funds as a claim that the nation is approaching a moment of crisis that science alone can address. That is not the only line of argument that has yielded money for science, and it is an approach that can backfire if promises fail to 